\title{
Between Solidarity and Self-Interest: The Elderly and Support for Public Education Revisited
}

\author{
MARIUS R. BUSEMEYER*(D) AND DOMINIK LOBER** \\ ${ }^{*}$ Professor of Political Science, University of Konstanz, Universitätsstr. 10, D-78457 \\ Konstanz, Germany \\ email: Marius.Busemeyer@uni-konstanz.de \\ ${ }^{* * D o c t o r a l}$ Researcher, University of Konstanz, Universitätsstr. 10, D-78457 Konstanz, \\ Germany \\ email: Dominik.Lober@uni-konstanz.de
}

\begin{abstract}
Proceeding population aging might fuel generational conflicts about the distribution of welfare state resources in the future, but the existing evidence on the extent of generational cleavages in attitudes towards the welfare state is mixed. We argue that these mixed findings are partially related to an underestimation of trade-offs on the level of individual preferences. Using novel data from a survey experiment conducted in eight Western European countries, we show that age-related self-interest is an important determinant of social policy preferences. When elderly respondents are confronted with hypothetical cutbacks in pensions, they are much less likely to support additional education spending. However, we also find evidence for a mediating effect of social trust: high-trusting elderly individuals are more likely to support education spending - contrary to their narrow self-interest - than low-trusting elderly.
\end{abstract}

Keywords: intergenerational solidarity; age-based self-interest; generational conflict; education spending; social trust; political ideology; trade-offs; public opinion

\section{Introduction}

In the large majority of post-industrial welfare states in the Western world, population aging will significantly increase public expenditures in the coming years in policy areas such as health care and pensions (Goerres and Vanhuysse, 2012). Since population aging also contributes to a rising influence of elderly voters during elections (Goerres, 2009), some scholars and pundits predict the emergence of generational conflicts about the distribution of scarce welfare state resources, in which younger generations are expected to be increasingly disadvantaged (Sinn and Uebelmesser, 2002). A necessary condition for the emergence of a large-scale generational conflict about welfare state policies is that older and younger generations in fact have different preferences regarding social policy. So far, however, the evidence for the existence of a generational cleavage 
in welfare state attitudes and preferences is mixed. Some studies find no evidence for such a cleavage (Arber and Attias-Donfut, 2000; Naumann, 2014), while others confirm that age-related self-interest is a significant determinant of preferences for social policies: with the elderly being more opposed to increasing spending on education, for instance (Bonoli and Häusermann, 2009; Busemeyer et al., 2009; Cattaneo and Wolter, 2009). A third line of research highlights the role of intergenerational solidarity and social capital in mitigating the effects of self-interest (Berkman and Plutzer, 2004; Goerres and Tepe, 2010; Street and Cossman, 2006). This perspective suggests that the elderly might support policies that primarily benefit younger generations because of family ties or concerns about social solidarity.

This paper contributes to this debate by providing new evidence from an original survey of public opinion in eight Western European countries. In contrast to existing international comparative surveys such as the European Social Survey (ESS) or the International Social Survey Programme (ISSP), this survey employs more sophisticated instruments, which take into account political and fiscal trade-offs between different categories of public spending. Including spending constraints in question wording comes closer to decision processes in the real world of policy-making in the "era of permanent austerity" (Pierson, 2001), when political actors are regularly confronted with difficult fiscal trade-offs. In the words of Kuklinski, Quirk, Jerit, and Rich (2001: 415): "Making tradeoffs is as central to the judgment of policy as voting is to electoral democracy." Thus, the primary goal of our paper is to provide a more robust and reliable assessment of whether a generational cleavage really exists and, if so, whether interpersonal trust is a factor that mediates this cleavage. We do this by studying the association between old age and public support for a policy area that primarily benefit younger generations: education.

To briefly foreshadow our main findings: our analysis largely confirms self-interest based accounts. Support for additional spending on education drops significantly among the elderly, in particular when the question wording mentions spending constraints that would directly affect older people. However, we find some support for the notion that social trust fosters intergenerational solidarity by mitigating the negative association between old age and support for education spending, but this counterbalancing effect cancels out the selfinterest mechanism only under specific circumstances.

\section{Self-interest and solidarity in face of trade-offs}

A standard argument in the large and ever growing literature on welfare state attitudes is that individual preferences are to a large extent driven by material self-interest, defined by income, educational background, skills or labor market risk (see e.g. Cusack et al., 2006; Finseraas, 2009; Iversen and Soskice, 2001; 
Rehm, 2009; Rehm et al., 2012). According to this literature, demand for redistribution increases with declining income and rising risks. Besides income, education, and risk, age can be a defining category for self-interest as well (Busemeyer et al., 2009). This is because some policies are geared towards supporting individuals in a particular income or socio-economic position (social assistance or unemployment insurance), while others are directed at particular stages in the life cycle (pensions, education; this applies partly but not fully to health care too). A straightforward argument based on age-related self-interest is therefore that elderly people should be more opposed to policies and spending programs that primarily benefit younger generations (education and family care policies) and instead should be in favor of spending increases on old-age related programs such as pensions and partially health care.

The empirical evidence for age-based self-interest is rather mixed, however. Some analyses of actual spending patterns find that spending for the young is negatively associated with the population share of older people (Poterba, 1997; Rattsø and Sørensen, 2010). This is backed up by survey research, which shows that older people tend to support pro-elderly spending, but oppose increasing expenditures in favor of younger generations (Bonoli and Häusermann, 2009; Busemeyer et al., 2009; Cattaneo and Wolter, 2009; Goerres and Tepe, 2012; Sørensen, 2013; Svallfors, 2008). Other scholars find less evidence for a strong age-based cleavage. Several studies question the supposedly strong association between a large population share of the elderly and a pro-elderly bias in welfare expenditures (Bradshaw and Holmes, 2013; Berkman and Plutzer, 2004; Pampel, 1994; Tepe and Vanhuysse, 2009). Moreover, some studies on attitudes and preferences find evidence that older people do not solely concentrate on maximizing their own benefits and that they are actually willing to support spending to the benefit of the younger generations (Goerres and Tepe, 2010; Logan and Spitze, 1995; Street and Cossman, 2006).

A significant shortcoming of existing studies of popular attitudes towards the welfare state is that they do not take into account spending constraints and fiscal trade-offs in a sufficient manner. Some public policies such as education are widely popular among the electorate with huge majorities supporting more public investments in this policy area (Ansell, 2010, p. 136; Busemeyer, 2012). However, given the deficiencies of available survey data, it is unknown how stable this support is. For instance, support for education spending among the elderly could drop significantly if this would depend on lower spending on health care or pensions (Street and Cossman, 2006, p. 93). In other words, self-interest might become a more important determinant of policy preferences compared to notions of social solidarity in constrained settings, when individuals are confronted with difficult trade-off decisions (Busemeyer and Garritzmann 2017). Since other surveys (and studies using these data) do not consider this in a satisfactory manner, the existence and severity of a 
generational cleavage might have been underestimated so far. Therefore, our first hypothesis, applying the general argument about age-related self-interest to the case of education, states that:

Hypothesis 1: The elderly should be opposed to spending increases on education policy, in particular in constrained scenarios when spending increases on education would have to be financed with cutbacks in other parts of the welfare state, tax increases or debt hikes.

Critics might object to this rather narrow reading of economic self-interest. If one adopts a broader perspective on self-interest, the elderly might support additional investments in education out of a sense of enlightened self-interest. They could be convinced that additional public investments in education will have positive benefits on the long-term competitiveness of their country's economy, which also affects the fiscal sustainability of the welfare state upon which they depend (Boldrin and Montes, 2005). Furthermore, the elderly might support education spending because it increases the quality of local schools, which in turn has a positive effect on housing values (Brunner and Balsdon, 2004). Empirically, these arguments are difficult to verify since surveys usually do not ask people why they support particular policies. What is more, it seems plausible to argue that the role of "enlightened self-interest" is particularly small in constrained settings, when respondents are confronted with actual cutbacks in policies from which they directly benefit.

What is more, older people might be supportive of education spending due to social network effects (Goerres and Tepe, 2010). When elderly respondents have children (or grandchildren) of their own, they should be more inclined to express solidarity and therefore a higher degree of support for pro-young spending. The underlying mechanism for this association might be related to altruism, but it could also be interpreted as a form of enlightened self-interest, i.e. respondents are interested in expanding those policies that benefit their offspring and therefore indirectly themselves. Unfortunately, our data does not allow us to test the social network effect directly since we lack sufficiently detailed information on family structures.

Instead, in this paper, we focus on the role of interpersonal social trust as a potential factor mediating the effect of self-interest. We argue that trust plays an important role in building solidarity across generations - all the more so if solidarity towards others implies personal costs. Going back to the seminal work by Rothstein (1998), scholarly knowledge on the relationship between political and social trust on the one hand and support for the welfare state on the other has advanced significantly (see Kumlin et al. (2017) for a recent overview of that literature). What is less explored in this literature is the connection between trust and social solidarity. Ultimately, building trust in the welfare state requires some degree of solidarity between citizens themselves. Therefore, if trust declines, it should have severe consequences for solidarity. Soroka et al. (2007) examine this 
nexus in the context of ethnic diversity and support for the welfare state in Canada. The argument is that racial heterogeneity decreases trust and, eventually, support for social programs. This argument is also promoted by social capital theorists showing that, in the medium-term, large-scale immigration decreases trust; with negative consequences for social solidarity (Putnam, 2007).

This link between trust and solidarity is further analyzed by Likki and Staerklé (2014) who find that people with a higher level of interpersonal trust are significantly more likely to support a societal order characterized by a high level of social solidarity and a low level of social control, and vice versa. The authors conclude that as trust mitigates fears of free riding and encourages people to rely on reciprocity, a higher level of trust increases the chance to support social solidarity as an important mode of societal organization. This association has direct consequences for the welfare state. It is shown that trust is positively related to support for the welfare state and redistributive policies (Daniele and Geys, 2015; Nagayoshi and Sato 2014; Sumino, 2014). Finally, these findings get support from analyses of aggregate-level data. Rothstein and Uslaner (2005) provide evidence in favor of a positive feedback cycle consisting of impartial government and high equality, trust, and solidarity, and Bergh and Bjørnskov $(2011,2014)$ find a causal relationship that links the current size of the welfare state to historical levels of trust.

In line with the gist of this literature, we argue that social trust is positively related to intergenerational solidarity in the sense that older people are more willing to support education spending - especially if this implies direct tradeoffs for themselves - when they show a higher level of trust towards others. This connection is less about decreasing fears of free riding, since this phenomenon should be less common in the area of education compared to issues like paying taxes. Instead, the mechanism builds on decreasing fears of getting exploited by others (Daniele and Geys, 2015) and on a greater confidence in reciprocity (Likki and Staerklé, 2014). Referring to preferences for youth-oriented social spending in constrained settings, this relation implies that older people with a high level of social trust are more likely to support increases in education spending as they are less afraid of the younger generations to take advantage of their goodwill and because they feel confident that the younger generations will support them if they need their help. Therefore, our second hypothesis reads as follows:

Hypothesis 2: The negative association between age-based self-interest and support for proyoung spending is expected to be less pronounced for individuals expressing a high degree of social trust.

Ex ante, it is an open question whether the mitigating effects of social trust become stronger or weaker in more constrained choice scenarios. As stated in Hypothesis 1, age-based self-interest as a factor determining preferences for 
youth-oriented social spending should become stronger relative to other factors in constrained scenarios because respondents are made aware of the costs associated with hypothetical spending increases. This implies that the direct association between social trust and support for education spending should be weaker in the constrained compared to the unconstrained scenarios. However, this does not necessarily extend to the interaction effects under examination. On the one hand, the dominating impact of self-interest in constrained scenarios might be so strong that it also negates the mediating impact of other factors. On the other hand, one could argue that the mitigating effect of social trust on self-interest should actually be strongest in the constrained scenarios, because this is where self-interest most clearly comes to the fore so that differences related to trust become more important within the group of those supporting spending despite constraints. From a theoretical perspective, both alternatives are plausible, which is why we leave this question open to empirical investigation.

\section{Data, Methods, and Variables}

The two hypotheses identified above will be tested using a range of questions from an original survey of public opinion in eight Western European countries ${ }^{1}$, which was conducted in the project "Investing in Education in Europe (INVEDUC)" (see Busemeyer et al., 2017 for details). The fieldwork for the survey took place in 2014, and the dataset contains a maximum number of 8.905 respondents. The survey contains several questions, which aim at comparing preferences for different kinds of spending in a constrained and unconstrained setting, which we will present in the sub-sections below. Responses are usually coded on a five-point scale, which we transform into a binary measure indicating strong (or very strong) support for a particular statement or spending type. This is done to facilitate the interpretation of regression results and the readability of the output. For the multivariate regression analyses, we employ logit regression models with country dummies and robust standard errors to take into account the clustering of individuals within countries. Alternative model specifications are tested in the robustness section in the Appendix.

All analyses use the same set of control variables. The main independent variable is, of course, the respondent's age. We use three different operationalizations of this variable. The first is simply the exact age of the respondent. In the robustness section, we test the second operationalization, which is an indicator of whether the respondent is retired. The third measure captures distinct age groups in the form of a categorical variable. Using these different operationalizations is important for several reasons. First, the association between age and spending support might be non-linear with people in the middle of their working careers expressing different kinds of demands on the welfare state compared to the very young who might still be in education and the elderly who are out of 
the labor force. Therefore, it is necessary to include a categorical measure of age to be able to distinguish between different stages of the life cycle. Second, including a dummy variable indicating whether someone is retired or not is important, because the retirement age might differ across countries as well as across socioeconomic classes. At the same time, moving from active participation in the labor force to the retirement is linked to a significant transformation of the relationship between an individual and the welfare state, since individuals' livelihood depends on public transfers in retirement. Hence, the retirement dummy variable can pick up these effects independent of the exact age when somebody retires. Since all three variables are obviously correlated, we use them in different regression models.

Social trust is measured by respondents' replies to the statement "that most people can be trusted or that [one] can't be too careful in dealing with people" on an 11-point scale. A low value indicates low levels of trust, whereas a high value signifies the opposite. Furthermore, we include political ideology as a control variable, captured by the respondents' self-placement in response to the following question: "In politics people sometimes talk of 'left' and 'right'. Where would you place yourself on this scale, where o means the left and 10 means the right?" Income is given in income quintiles, based on country-specific distributions of incomes, which take into account differences in purchasing power. Previous studies have shown that the association between income and support for education spending is weak, because education is less redistributive compared to other social policies (Ansell, 2010, Chapter 4; Busemeyer, 2012; Garritzmann, 2015). In contrast, educational background - operationalized as the respondent's highest level of education or training completed based on a five-point scale ranging from basic/lower secondary education via secondary to higher education completed - should be positively associated with support for education spending since highly educated individuals have been found to be more supportive of further spending on education (Busemeyer, 2012). The gender of respondents (coded as 1 for women) is expected to matter in the sense that women are usually more supportive of greater state involvement (Svallfors, 1997). We also control for the presence of children in the household (similar to Goerres and Tepe (2010)). The straightforward expectation is that individuals with children at home should be more likely to support pro-young types of spending.

To evaluate the determinants of the respondents' preferences for increasing education spending we use a simple survey experiment. This allows us to control for the impact of various fiscal constraints and trade-offs on people's support for higher education spending on the one hand, and to examine changes in the influence of self-interest, social trust, and ideology on support for education spending as a consequence of introducing constraints on the other hand. Each of the following questions is presented to a subsample of the whole sample 
of respondents, whereby people are randomly assigned to the groups. This gives us around 2,000 observations per group.

The first group of respondents was asked: "The government should increase spending on education. Do you: strongly agree; agree; neither agree nor disagree; disagree; strongly disagree?" This question measures overall support for education spending regardless of potential costs, which is similar to what is done in most other surveys. The second and third question add constraints related to taxes and public debt when asking for respondent's support for education spending: "The government should increase spending on education, even if that implies a higher public debt. Do you ..." And: "The government should increase spending on education, even if that implies higher taxes. Do you ...". The final group was confronted with a scenario pointing to a direct trade-off between social policy programs: "The government should increase spending on education, even if that implies cutting back spending in other areas such as pensions. Do you ...". Corresponding to Hypothesis 1 , we expect that age-related self-interest appears more clearly in the constrained settings with the strongest effect to be observed in the last group.

\section{Empirical Analysis}

\section{Descriptive analysis}

Figure 1 shows the average support of various age groups for education spending across the different scenarios. ${ }^{2}$ The first age group consists of all respondents younger than 35 and serves as reference group. The following age groups capture the respondents in ten-year steps until the age of 64. All respondents at the age of 65 or older are included in the last group. The figure confirms that increasing education spending is a very popular policy proposal independent of the respondent's age, which resonates well with previous findings (Ansell, 2010; Busemeyer, 2012). The average support for people younger than 35 is almost 80 percent. Even among the oldest respondents the level of support is quite high: two out of three people older than 64 are in favor of higher education spending when no trade-off is mentioned.

However, things clearly change as soon as respondents are confronted with fiscal constraints and spending trade-offs. Although increasing taxes is commonly assumed to be highly unpopular, more than half of the respondents at all stages of the life cycle would be willing to accept higher taxes in order to increase spending on education. Of course, average support decreases significantly compared to the unconstrained setting. Nevertheless, people are more willing to accept higher taxes in exchange for education spending rather than higher levels of public debt. Even in the youngest age group - the main profiteers of higher education spending - average support for education spending in exchange for more public debt does not reach 50 percent. This strong opposition 


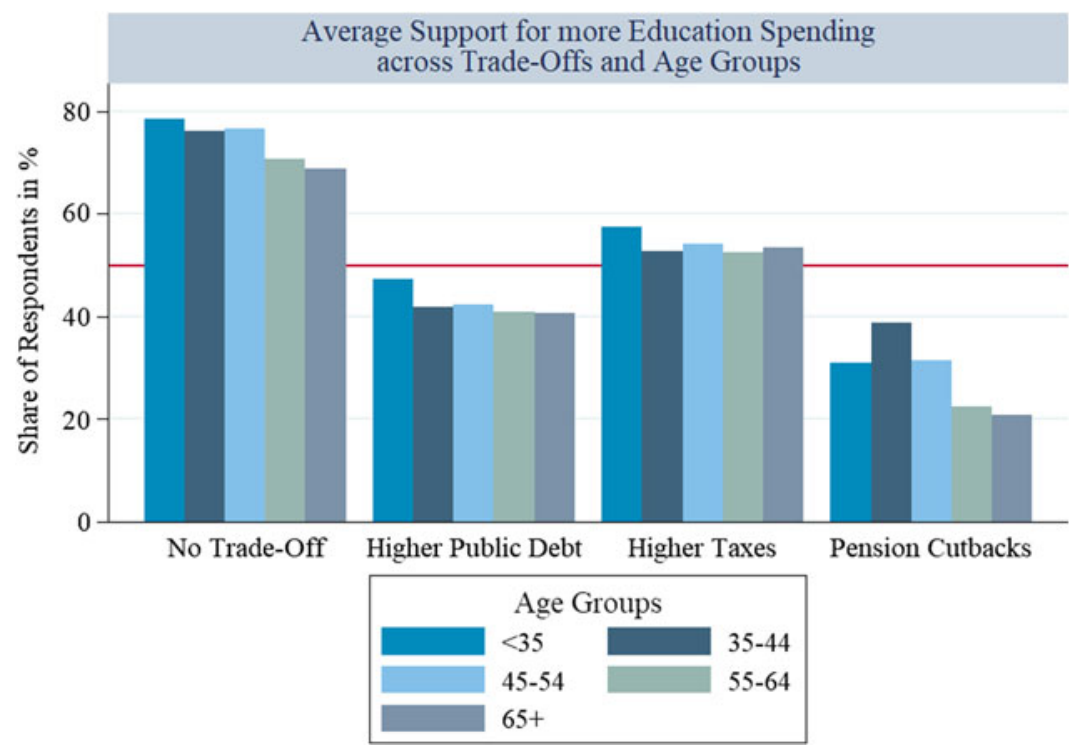

FIGURE 1. Average Support for Higher Education Spending (Share of respondents supporting "more" or "much more" education spending).

to higher public debt could be an aftershock of the sovereign debt crisis in many European countries or it could be a genuine skepticism to finance additional public spending with debt.

Finally, cutting back pensions is even less popular than increasing public debt across all age groups. While the differences between the age groups are quite remarkable, any of the groups reaches an average level of support of at least 40 percent. Instead, average support of the youngest and the middle-age group fluctuates around 30 percent and drops to slightly more than 20 percent for the oldest respondents. Referring to our first hypothesis, Figure 1 partially confirms our expectations. Average rates of support for further education spending are higher among the young and decline with increasing age. This is a clear indication for the existence of an age-related cleavage in public support for education spending, confirming previous findings in the literature (Busemeyer et al., 2009; Cattaneo and Wolter, 2009).

Hypothesis 1 also entails the claim that the size of the age cleavage should differ across the scenarios. The difference between the youngest and the oldest respondents is higher in the unconstrained setting - where the average support drops by ten percentage points from around 78 percent to 68 percent - than in the scenarios with increasing public debt ( 47 percent vs. 40 percent) or taxes ( 57 percent vs. 53 percent). The age cleavage is strongest in the scenario mentioning pension cuts. While the effect of age appears to be non-linear - the average 

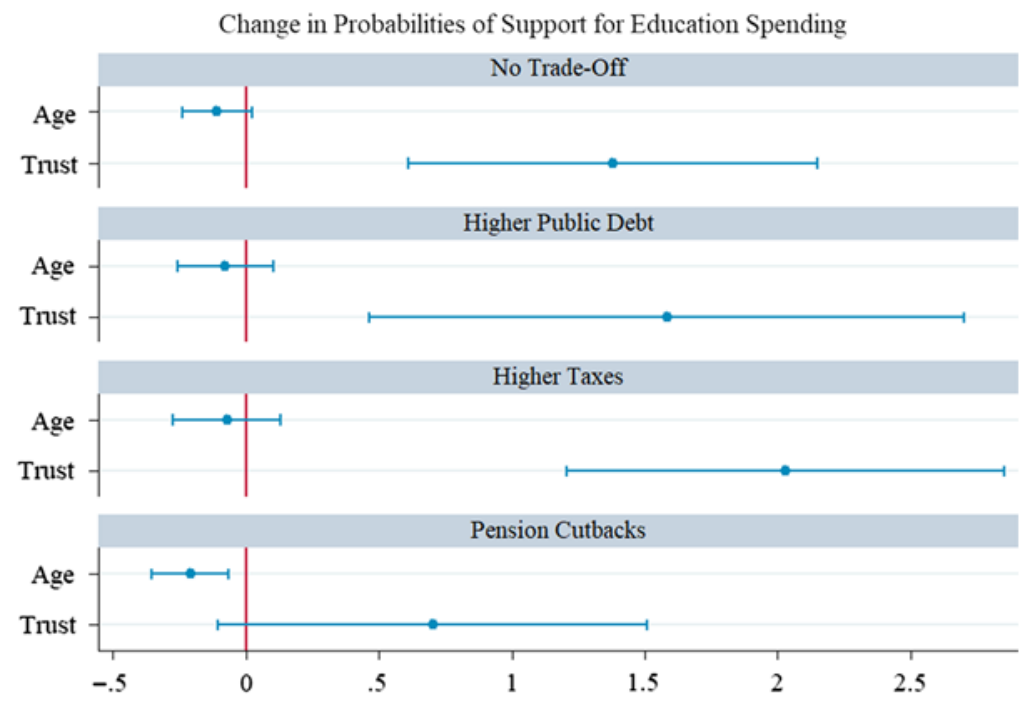

Note: $95 \%$ Confidence Interval

FIGURE 2. Determinants of Change in Probabilities of Support for Education Spending (only main independent variables are shown).

support increases from almost 31 percent in the youngest age group to almost 39 percent among those between 35 and $44-$-, support for youth-oriented spending drops most significantly for the last two age groups comprising respondents at the age of 55 and older ( 22 percent and slightly less than 21 percent, respectively). In this setting, older respondents clearly see their own benefits endangered which makes them more opposed to increases in education spending. However, the descriptive analysis does not provide clear-cut evidence for our expectation that the size of the age-related cleavage is strongest in the most constrained scenario, which is why we turn to the multivariate analysis next.

\section{Multivariate analysis}

In a first step, we analyze the direct effects ${ }^{3}$ of age and social trust on support for education spending across the different scenarios, before we explore the interaction effects in a second step. The results for the first step for our main independent variables are presented graphically in Figure 2, which presents predicted changes in the probability of supporting more education spending. ${ }^{4}$ The full regression models are shown in Table 1.

Figure 2 confirms the existence of an age cleavage, but the age coefficient is only statistically significant in the last scenario involving the possibility of pension cuts. In terms of effect size, this age coefficient implies that the probability of supporting more (or much more) education spending decreases by 0.2 percentage points for a one-unit increase in age (one year), or by 3.34 percentage points 
TABLE 1. Determinants of support for education spending

\begin{tabular}{|c|c|c|c|c|}
\hline & $\begin{array}{l}\text { (1) } \\
\text { No Trade-Off }\end{array}$ & $\begin{array}{l}(2) \\
\text { Higher Debt }\end{array}$ & $\begin{array}{l}\text { (3) } \\
\text { Higher Taxes }\end{array}$ & $\begin{array}{l}\text { (4) } \\
\text { Pension Cuts }\end{array}$ \\
\hline Age & $\begin{array}{c}-0.006^{*} \\
(0.00)\end{array}$ & $\begin{array}{c}-0.003 \\
(0.00)\end{array}$ & $\begin{array}{c}-0.003 \\
(0.00)\end{array}$ & $\begin{array}{c}-0.012^{* * *} \\
(0.00)\end{array}$ \\
\hline Trust & $\begin{array}{c}0.078^{* * * *} \\
(0.02)\end{array}$ & $\begin{array}{c}0.065^{* * * *} \\
(0.02)\end{array}$ & $\begin{array}{c}0.082^{* * * *} \\
(0.02)\end{array}$ & $\begin{array}{l}0.040^{*} \\
(0.02)\end{array}$ \\
\hline Political Ideology & $\begin{array}{c}-0.112^{* * *} \\
(0.03)\end{array}$ & $\begin{array}{c}-0.110^{* * *} \\
(0.03)\end{array}$ & $\begin{array}{c}-0.100^{* * *} \\
(0.03)\end{array}$ & $\begin{array}{l}-0.012 \\
(0.02)\end{array}$ \\
\hline Female & $\begin{array}{l}0.113 \\
(0.11)\end{array}$ & $\begin{array}{l}0.007 \\
(0.10)\end{array}$ & $\begin{array}{c}-0.068 \\
(0.13)\end{array}$ & $\begin{array}{l}-0.130 \\
(0.12)\end{array}$ \\
\hline Education Level & $\begin{array}{c}0.145^{* * *} \\
(0.05)\end{array}$ & $\begin{array}{l}0.053 \\
(0.05)\end{array}$ & $\begin{array}{l}0.039 \\
(0.04)\end{array}$ & $\begin{array}{l}0.045 \\
(0.07)\end{array}$ \\
\hline Income & $\begin{array}{c}-0.029 \\
(0.05)\end{array}$ & $\begin{array}{c}-0.041^{*} \\
(0.02)\end{array}$ & $\begin{array}{l}0.026 \\
(0.05)\end{array}$ & $\begin{array}{l}0.037 \\
(0.03)\end{array}$ \\
\hline Children in the $\mathrm{HH}$ & $\begin{array}{l}0.102 \\
(0.18)\end{array}$ & $\begin{array}{l}0.108 \\
(0.11)\end{array}$ & $\begin{array}{l}0.307^{* *} \\
(0.13)\end{array}$ & $\begin{array}{c}0.463^{* * *} \\
(0.16)\end{array}$ \\
\hline Constant & $\begin{array}{c}1.476^{* * *} \\
(0.25)\end{array}$ & $\begin{array}{c}-0.104 \\
(0.46)\end{array}$ & $\begin{array}{l}0.298 \\
(0.45)\end{array}$ & $\begin{array}{c}-0.666^{* *} \\
(0.32)\end{array}$ \\
\hline Observations & 1,832 & 1,764 & 1,797 & 1,744 \\
\hline$B I C$ & $1,971.888$ & $2,386.864$ & $2,373.296$ & $2,059.773$ \\
\hline Log Likelihood & -959.648 & $-1,167.268$ & $-1,160.419$ & $-1,003.763$ \\
\hline
\end{tabular}

Standard errors in parentheses. Standard errors clustered by country; Country-dummies included but not shown. ${ }^{*} p<0.10,{ }^{* *} p<0.05,{ }^{* * *} p<0.01$.

for a one standard deviation increase in age (16.7 years). Simulating the difference between two women, without children in the household and all other variables at their means, one of them aged 37.6 (one standard deviation below the mean age) and the other aged 71 (one standard deviation above the mean age), yields predicted probabilities of supporting education spending of 26.5 percent and 19.5 percent, respectively. ${ }^{5}$ This simulation highlights two points: first, cutting pensions to increase education spending is fairly unpopular, and, second, the age of respondents plays a significant role in this respect. As mentioned above (Fn. 4), Figure $A_{1}$ in the Appendix (Supplementary Materials) repeats the analysis underlying Figure 2 but using $\mathrm{x}$-standardized variables instead. This reveals that the magnitude of age-based self-interest is similar to the size of the coefficient estimates of social trust, which is not immediately clear from Figure 2.

The association between social trust and spending support shows a rather different pattern: in Models 1 to 3 , the coefficient is statistically significant and positive, but it loses strength and significance in the last model. This is basically in line with our expectation of a positive association between trust in other people and support for education spending. This relationship holds regardless of whether spending increases would go along with higher levels of public debt or higher taxes. In terms of probabilities, when all variables - except gender and the binary variable for whether there are children in the household - are 
AME of Age on Probability of Support for Education Spending
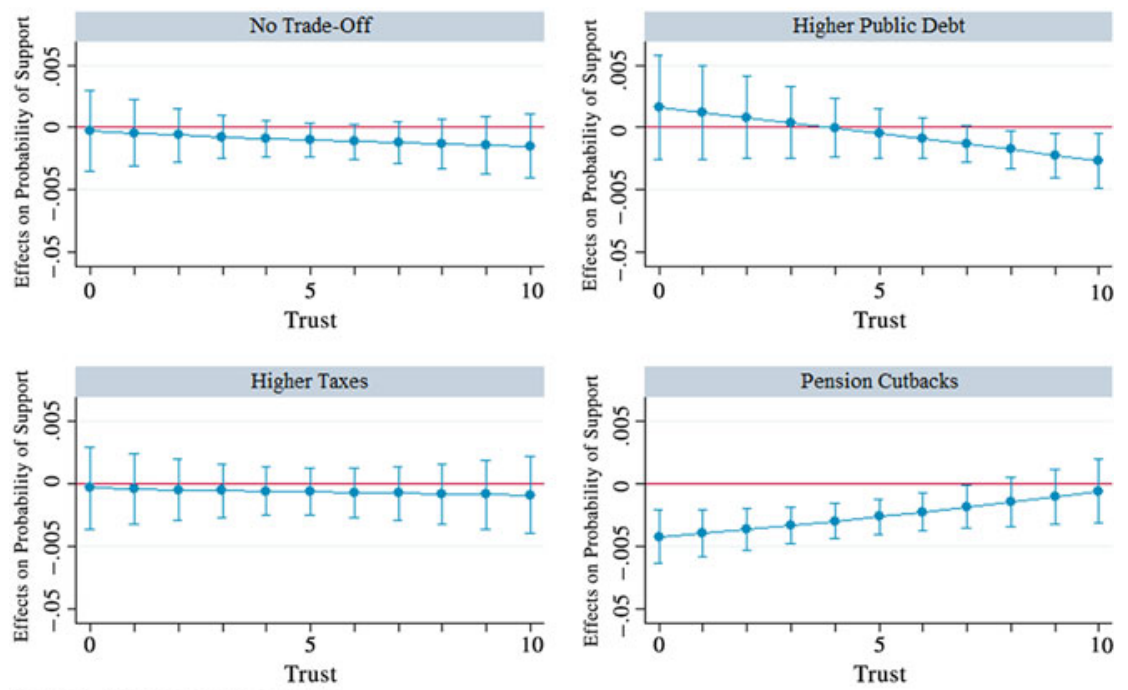

Note: $0=$ 'You can't be too careful',

$10=$ 'Most people can be trusted';

$95 \%$ Confidence Interval

FIGURE 3. Average Marginal Effects of Age on the Probability of Support for Education Spending, Depending on Respondents' Level of Social Trust.

held at their means, the effects of social trust in Models 1 to 3 vary between an increase of support by 3.6 and 5.2 percentage points for a one standard deviation increase in trust (2.6 units). All the effects are significant at the 1 percent level. However, things change in Model 4 . The effect of trust is considerably smaller and only significant at the 10 percent level. This might indicate that high-trusting respondents are conflicted by having to prioritize between different social policy areas, which in turn weakens the statistical association between trust and spending support. To better understand what this means in practice, we again compare the two women introduced earlier. In the first case, the level of social trust is set at the mean, while, in the latter one, it is set at one standard deviation above the mean. This is associated a significant increase in the probability of supporting higher education spending in the unconstrained scenario of 3.4 percentage points.

In the next step, we analyze the interaction effects between age, social trust and assignment to the different treatment groups. Following the recommendations by Brambor et al. (2006), we display the interactions graphically in Figures 3 and 4 (as well as Figure A2 in the Appendix, Supplementary Materials). More detailed regression analyses can be found in Tables $\mathrm{A}_{1}$ and $\mathrm{A}_{2}$ in the Appendix (Supplementary Materials). 


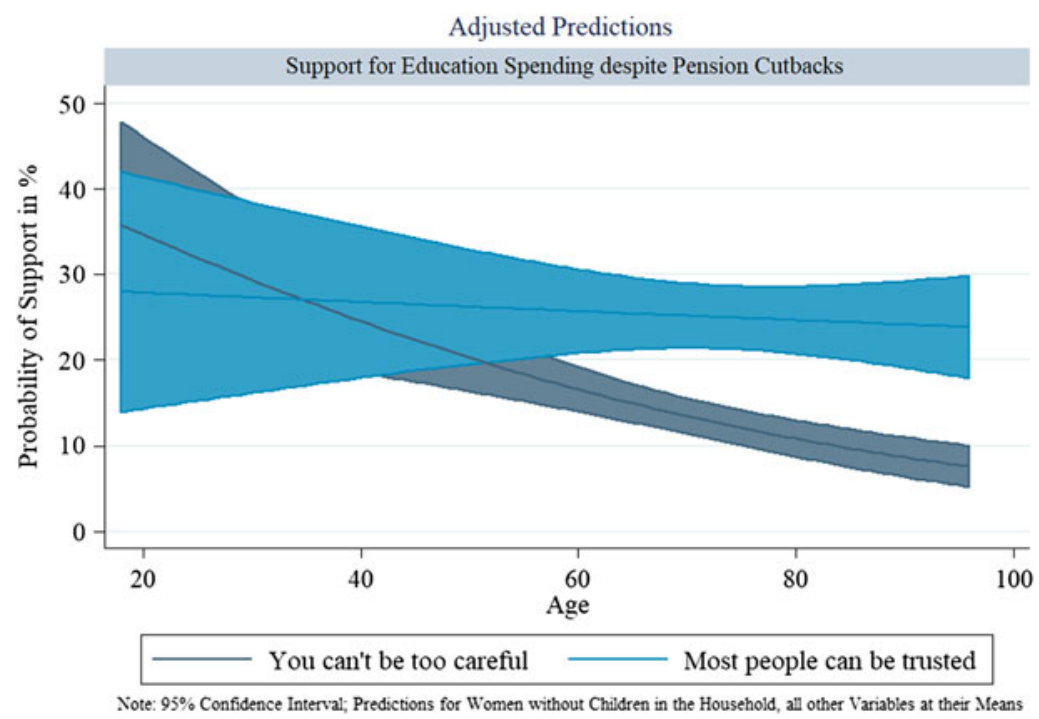

FIGURE 4. Adjusted Predictions: Support for Education Spending despite Pension Cutbacks.

Both of our hypotheses raise expectations about the heterogeneity of effects across different treatment groups. Hypothesis 1 implies that that the size of the age cleavage should vary across groups with a larger cleavage size to be observed in the more constrained scenarios. The regression analyses in Table A1 confirm the descriptive analysis in the sense that the evidence for this kind of effect heterogeneity is rather weak, even though the overall effect of age on support for education spending is negative (Model 1 in Table A1). Model 2 suggests that the negative relationship is strongest when more education spending comes at the expense of pension cutbacks, but still the interaction effect does not reach conventional levels of statistical significance.

This is different in the case of social trust (Model 3 in Table A1 as well as Figures 3 and 4). As a reminder, Hypothesis 2 argued that the social trust should mediate the expected negative association between age-based self-interest and spending support. Across the different models in Table A1 (as well as Figure 2 and Table 1 above), we find a positive and statistically significant association between social trust and spending support. We also find evidence for an interaction effect between age and social trust, but this association differs considerably across the different scenarios.

Figure 3 shows that the interaction between age and social trust reaches conventional levels of statistical significance only in the scenario when education spending would have to be financed with cutbacks in pension spending. As discussed above, from a theoretical perspective, it is theoretically ambiguous 
whether the interaction between social trust and self-interest should become stronger or weaker in the constrained scenario. The evidence clearly indicates the former: Older respondents expressing a high degree of social trust are more likely to accept cutbacks in pension spending in exchange for education spending compared to low-trusting individuals. Above, we hinted at the connection between social trust and intergenerational solidarity. This finding confirms this hunch in the sense that social trust matters most in those cases, where motivations related to self-interest are generally more prevalent and highlights the importance of social trust for solidarity across generations.

To emphasize the relevance of this relationship, we again compare women without children in the household, simulating an increase in age from a level one standard deviation below the mean ( 37.6 years) to a level one standard deviation above the mean (71 years). One group of women shows the highest level of social trust, while the other group consists of the most distrusting women. Figure 4 displays the results. ${ }^{6}$ It shows that women with a high level of social trust are almost equally supportive of education spending when traded off against pensions regardless of their age. Age-based self-interest has hardly any influence in this group. The younger woman has a probability of 27 percent to support higher education spending, whereas this probability merely decreases to 25 percent for the older woman. The opposite holds for low-trusting women. In this group, age-based self-interest has a significant influence decreasing the probability of support from 26 percent for a 37.6 years old woman to only 13 percent for a 71 years old woman. Hence, especially among older respondents there is a considerable gap in support between those who trust others and those who do not.

Considering the remaining three panels of Figure 3, we do not find any statistically significant association, confirming the hunch that social trust as a mediating factor matters most in highly constrained scenarios. In the scenario with no constraints and the one with tax increases, the slope of the interaction regression line is essentially flat. In the upper right panel of Figure 3, where higher education spending is linked to rising public debt, trust somewhat unexpectedly works in the opposite direction than assumed. In this case, low-trusting older people tend to support additional education spending despite higher levels of public debt, while their high-trusting fellows are significantly against it. This finding is rather puzzling at first sight, but it might be related to the fact that high-trusting elderly people are particularly reluctant to finance additional spending with public debt, even if this spending is directed at younger generations. At some point in the future, the younger generations who now benefit from additional education spending would have to repay the debt and suffer from severe cutbacks. Thus, the elderly with a high level of trust do not perceive it as an act of solidarity to support higher education spending at the costs of rising public debt and consequently reject it. 
Before we elaborate on the robustness of the findings, a short comment on the control variables: First, concerning political ideology, the results confirm that more conservative individuals generally oppose higher (education) spending, while their left-wing counterparts are in favor of such a policy. However, when benefits for distinct groups of recipients are traded against each other, left-wing and right-wing people no longer differ significantly in their preferences. This might indicate that those generally supporting the welfare state are conflicted in their preferences if they have to decide between two different policy areas (Busemeyer and Garritzmann, 2017). Second, the association between gender and spending support varies across the four models. While women are more supportive of education spending than men in the unconstrained setting and in the scenario where more education spending is trade off against higher public debt, the association turns negative when respondents are confronted with higher taxes and pension cutbacks, but none of the coefficients is statistically significant. Third, similar results are provided for income. The coefficient estimate is negative for the first two models and turns positive when higher taxes and pension cutbacks are mentioned as trade-offs. But again, none of the effects are significant. Fourth, regarding individual educational background, we find that the better educated people are more willing to support education spending as expected. However, the effect is significant only in the unconstrained setting indicating that highly educated individuals are reluctant to support education spending if this would have to be financed with higher public debt, tax increases, or spending cutbacks. Finally, Table 1 shows that the presence of children is relevant in the last two models. People with children living in the same household are more willing to support education spending, even when this is financed through higher taxes or pension cutbacks. This is also shown by Busemeyer and Garritzmann (2017) and corresponds to our expectations by reflecting some kind of (enlightened) self-interest.

To check the robustness of our findings, we estimate additional models (detailed results can be found in the Supplementary Materials). First, we estimate models with alternative operationalizations of age-based self-interest (dummy variable as indicator of retirement and categorical operationalizations of age groups to measure potential non-linear effects of age) as discussed above (Tables $\mathrm{A}_{3}$ and $\mathrm{A}_{4}$ in the Supplementary Materials). Second, we include attitudinal variables such as general preferences for spending and egalitarian attitudes (Tables A5, A6, A7 and A8, Supplementary Materials). Third, we employ ordered logit models - using an operationalization of the dependent variables with five response categories - instead of logit models (Tables A9 and A10, Supplementary Materials). Finally, we add a second interaction term between age and education to our regular model (Table A11, Supplementary Materials), because the interaction between age and trust might be driven by a third variable, i.e. education. This interaction is, however, insignificant and does not change the 
significant interaction between age and trust. By and large, these robustness checks confirm the main findings discussed above. Further details can be found in the Appendix (Supplementary Materials).

\section{Conclusions}

This paper contributes to the debate about generational cleavages in times of tight government budgets and rising demands on the welfare state related to population aging and the emergence of new social risks. Our first main finding is that age-based self-interest does matter, which confirms previous findings on this issue (Busemeyer et al., 2009; Cattaneo and Wolter, 2009). More specifically, we found evidence that age is negatively associated with support for education spending across the different treatment groups. We also found some indications that the size of the age cleavage is more pronounced in constrained settings, when education would be traded off against pension cutbacks, but the evidence for heterogeneous effects across the different groups is not ironclad. Still, we believe our finding is an important amendment to accounts emphasizing the notion of intergenerational solidarity, which might be overly optimistic as many existing surveys do not model fiscal trade-offs in their question wordings in a satisfactory manner. Thus, our findings in general emphasize the relevance of self-interest in preference formation and give rise to concerns about generational conflicts over scarce welfare benefits.

The second innovative contribution of the paper is to show that interpersonal trust can partly mitigate the association between self-interest and spending preferences. In particular, in constrained setting involved spending trade-offs between education and pensions, social trust mitigates the negative effect of old age and is even able to offset it completely for high levels of trust. Thus, when individuals are confronted with hard choices between different spending items, trust in other people becomes relevant to promote intergenerational solidarity in the welfare state. Beyond that, interpersonal trust has a significantly positive effect on support for education spending, and thus should be taken into account in future analyses.

Our findings also suggest some other issues for future research. Although people in post-industrial welfare states do not (yet) live in gerontocracies, as anticipated by some critics, our results show that age is strongly related to individual attitudes towards the welfare state, at least in the area of education spending. As population aging proceeds in mature welfare states, this topic should become even more important in the future and should motivate additional research on the importance of age-related cleavages in social policy preferences. Our findings imply that future research about policy preferences should take into account trade-offs in a more explicit manner. When public resources are scarce as in most mature welfare states, fiscal and the associated political 
trade-offs are ubiquitous. Critics might argue that solving these trade-offs is a task for policy-makers, not for citizens and voters, but we side with Kuklinski et al. (2001, p. 415) in positing that citizens' preferences regarding trade-offs can "give policymakers informative signals about their priorities". The relevance of trade-offs should also be investigated taking other social policy areas into account such as trade-offs between pension spending and benefits and services for families. Finally, one might also think about other factors mediating the association between age-based self-interest and social policy preferences in a manner similar to social trust, e.g. religiosity which could equally promote solidarity or social networks within and outside the family.

\section{Supplementary Materials}

To view supplementary material for this article, please visit https://doi.org/10. $1017 /$ So047279419000382.

\section{Acknowledgements}

Research for this project was funded by the Starting Grant 'Investing in Education from Europe: Attitudes, Politics and Policies' (INVEDUC) from the European Research Council (ERC), Grant No. 311769.

\section{Notes}

1. Sweden, Denmark, Germany, France, the UK, Ireland, Spain, and Italy.

2. More specifically, this is the average share of respondents expressing support for "more" or "much more" education spending.

3. Throughout this paper, whenever we talk about effects we do not claim to find causal mechanisms but rather correlations between two variables.

4. Note that the scale for age differs considerably from the scale for social trust: age ranges from 18 to 96 , while trust ranges only from o to 10 . This restricts the comparability of the effect sizes. To overcome this problem, we provide Figure A1 in the Appendix, showing the effects for $\mathrm{x}$-standardized variables. Although these coefficients should not be interpreted directly (Long and Freese (2014)), they are well-suited to compare effect sizes (Menard (2011)).

5. Throughout the analyses, we simulate results for women without children in the household as this is most representative. There are more female respondents and a majority lives in a household without children. Taking mean values of binary variables makes less sense.

6. Figure $\mathrm{A}_{2}$ in the Appendix provides yet another perspective on the interaction between age and social trust in the scenario involving pension cutbacks: It replicates the fourth panel in Figure 3 , but includes a rug plot of the trust measure in order to show that observations are distributed across the whole range of the scale.

\section{References}

Ansell, B.W. (2010), From the ballot to the blackboard: The redistributive political economy of education. Cambridge studies in comparative politics. Cambridge: Cambridge University Press. 
Arber, S. and Attias-Donfut, C. (Eds.) (2000), The myth of generational conflict: The family and state in ageing societies (1. publ), Routledge, European Sociological Association studies in European societies: Vol. 3. London: Routledge.

Bergh, A. and Bjørnskov, C. (2011), Historical trust levels predict the current size of the welfare state. Kyklos, 64(1), 1-19.

Bergh, A. and Bjørnskov, C. (2014), Trust, welfare states and income equality: Sorting out the causality. European Journal of Political Economy, 35, 183-199.

Berkman, M.B. and Plutzer, E. (2004), Gray peril or loyal support? The effects of the elderly on educational expenditures. Social Science Quarterly, 85(5), 1178-1192.

Boldrin, M. and Montes, A. (2005), The Intergenerational State Education and Pensions. Review of Economic Studies, 72(3), 651-664.

Bonoli, G. and Häusermann, S. (2009), Who wants what from the welfare state? European Societies, 11(2), 211-232.

Bradshaw, J. and Holmes, J. (2013), An analysis of equity in redistribution to the retired and children over recent decades in the OECD and UK. Journal of Social Policy, 42(1), 39-56.

Brambor, T., Clark, W.R. and Golder, M. (2006), Understanding interaction models: improving empirical analyses. Political Analysis, 14(1), 63-82.

Brunner, E. and Balsdon, E. (2004), Intergenerational conflict and the political economy of school spending. Journal of Urban Economics, 56(2), 369-388.

Busemeyer, M.R. (2012), Inequality and the political economy of education: An analysis of individual preferences in OECD countries. Journal of European Social Policy, 22(3), 219-240.

Busemeyer, M.R. and Garritzmann, J.L. (2017), Public opinion on policy and budgetary tradeoffs in European welfare states: evidence from a new comparative survey. Journal of European Public Policy, 24(6), 871-889.

Busemeyer, M.R., Garritzmann, J.L., Neimanns, E. and Nezi, R. (2017), Investing in education in Europe: evidence from a new survey of public opinion. Journal of European Social Policy, 73(4), 1-21.

Busemeyer, M.R., Goerres, A. and Weschle, S. (2009), Attitudes towards redistributive spending in an era of demographic ageing: the rival pressures from age and income in 14 OECD countries. Journal of European Social Policy, 19(3), 195-212.

Cattaneo, M.A. and Wolter, S.C. (2009), Are the elderly a threat to educational expenditures? European Journal of Political Economy, 25(2), 225-236.

Cusack, T., Iversen, T. and Rehm, P. (2006), Risks at work: the demand and supply sides of government redistribution. Oxford Review of Economic Policy, 22(3), 365-389.

Daniele, G. and Geys, B. (2015), Interpersonal trust and welfare state support. European Journal of Political Economy, 39, 1-12.

Finseraas, H. (2009), Income inequality and demand for redistribution: a multilevel analysis of European public opinion. Scandinavian Political Studies, 32(1), 94-119.

Garritzmann, J.L. (2015), Attitudes towards student support: how positive feedback-effects prevent change in the four worlds of student finance. Journal of European Social Policy, 25(2), 139-158.

Goerres, A. (2009), The Political Participation of Older People in Europe: The Greying of our Democracies (1. publ). Basingstoke: Palgrave Macmillan.

Goerres, A. and Tepe, M. (2010), Age-based self-interest, intergenerational solidarity and the welfare state: a comparative analysis of older people's attitudes towards public childcare in 12 OECD countries. European Journal of Political Research, 49(6), 818-851.

Goerres, A. and Tepe, M. (2012), Doing it for the kids? The determinants of attitudes towards public childcare in unified Germany. Journal of Social Policy, 41(2), 349-372.

Goerres, A. and Vanhuysse, P. (2012), Mapping the field: comparative generational politics and policies in ageing democracies. In: P. Vanhuysse and A. Goerres (Eds.), Ageing Populations in Post-industrial Democracies. (pp. 1-22). London: Routledge. 
Hansen, J.M. (1998), Individuals, institutions, and public preferences over public finance. American Political Science Review, 92(3), 513-531.

Iversen, T. and Soskice, D. (2001), An asset theory of social policy preferences. American Political Science Review, 95(4), 875-893.

Kumlin, S., Stadelmann-Steffen, I. and Haugsgjerd, A. (2017), Political trust and the welfare state. In: E.M. Uslaner (Ed.), Oxford Handbook of Social and Political Trust. (pp. 385-408). Oxford: Oxford University Press.

Kuklinski, J.H., Quirk, P.J., Jerit, J. and Rich, R.F. (2001), The Political Environment and Citizen Competence. American Journal of Political Science, 45(2), 410-424.

Likki, T. and Staerklé, C. (2014), A Typology of Ideological Attitudes Towards Social Solidarity and Social Control. Journal of Community \& Applied Social Psychology, 24(5), 406-421.

Logan, J.R. and Spitze, G.D. (1995), Self-Interest and Altruism in Intergenerational Relations. Demography, 32(3), 353-364.

Long, J.S. and Freese, J. (2014), Regression models for categorical dependent variables using stata (3rd ed.), College Station, Tex.: Stata Press.

Menard, S. (2011), Standards for standardized logistic regression coefficients. Social Forces, $89(4), 1409-1428$.

Nagayoshi, K. and Sato, Y. (2014), Who supports redistributive policies in contemporary Japan? An integrative approach to self-interest and trust models. International Sociology, 29(4), 302-323.

Naumann, E. (2014), Increasing conflict in times of retrenchment? Attitudes towards healthcare provision in Europe between 1996 and 2002. International Journal of Social Welfare, 23(3), 276-286.

Pampel, F.C. (1994), Population aging, class context, and age inequality in public spending. American Journal of Sociology, 100(1), 153-195.

Pierson, P. (2001), Coping with permanent austerity welfare state restructuring in affluent democracies. In: P. Pierson (Ed.), The New Politics of the Welfare State (pp. 410-456). Oxford: Oxford University Press.

Poterba, J.M. (1997), Demographic structure and the political economy of public education. Journal of Policy Analysis and Management, 16(1), 48-66.

Putnam, R.D. (2007), E pluribus unum: diversity and community in the twenty-first century the 2006 Johan Skytte prize lecture. Scandinavian Political Studies, 30(2), 137-174.

Rattsø, J. and Sørensen, R.J. (2010), Grey power and public budgets: family altruism helps children, but not the elderly. European Journal of Political Economy, 26(2), 222-234.

Rehm, P. (2009), Risks and redistribution: an individual-level analysis. Comparative Political Studies, 42(7), 855-881.

Rehm, P., Hacker, J.S. and Schlesinger, M. (2012), Insecure alliances: risk, inequality, and support for the welfare state. American Political Science Review, 106(2), 386-406.

Rothstein, B. (1998), Just institutions matter: The moral and political logic of the universal welfare state. Cambridge: Cambridge University press.

Rothstein, B. and Uslaner, E.M. (2005), All for all: equality, corruption, and social trust. World Politics, 58(1), 41-72.

Sinn, H.-W. and Uebelmesser, S. (2002), Pensions and the path to gerontocracy in Germany. European Journal of Political Economy, 19(1), 153-158.

Sørensen, R.J. (2013), Does aging affect preferences for welfare spending? A study of peoples' spending preferences in 22 countries, 1985-2006. European Journal of Political Economy, 29, 259-271.

Soroka, S.N., Johnston, R. and Banting, K. (2007), Ethnicity, trust, and the welfare state. In F. Kay and R. Johnston (Eds.), Equality, Security, Community. Social Capital, Diversity, and the Welfare State (pp. 279-304). Vancouver, BC: UBC Press.

Street, D. and Cossman, J.S. (2006), Greatest generation and Greedy Geezers? Social spending preferences and the Elderly. Social Problems, 53(1), 75-96. 
Sumino, T. (2014), Escaping the curse of economic self-interest: an individual-level analysis of public support for the welfare state in Japan. Journal of Social Policy, 43(1), 109-133. Svallfors, S. (1997), Worlds of welfare and attitudes to redistribution: a comparison of eight Western Nations. European Sociological Review, 13(3), 283-304.

Svallfors, S. (2008), The generational contract in Sweden: age-specific attitudes to age-related policies. Policy \& Politics, 36(3), 381-396.

Tepe, M. and Vanhuysse, P. (2009), Are aging OECD Welfare states on the path to gerontocracy? Evidence from 18 Democracies, 1980-2002. Journal of Public Policy, 29(1), 1-28. 